\title{
Cellular networks controlling Th2 polarization in allergy and immunity Mirjam Kool ${ }^{1,2}$, Hamida Hammad ${ }^{1,3}$ and Bart N. Lambrecht ${ }^{1,2,3 *}$
}

\author{
Addresses: ${ }^{1}$ Laboratory of Immunoregulation and Mucosal Immunology, Department of Respiratory Diseases, University Hospital, Ghent, \\ Belgium; ${ }^{2}$ Department of Pulmonary Medicine, Erasmus University Medical Centre, Rotterdam, The Netherlands; ${ }^{3}$ Department of Molecular \\ Biomedical Research, Flemish Institute of Biotechnology, VIB, Ghent, Belgium \\ *Corresponding author: Bart N. Lambrecht (bart.lambrecht@dmbr.vib-ugent.be) \\ FI000 Biology Reports 2012, 4:6 (doi:10.3410/B4-6) \\ This is an open-access article distributed under the terms of the Creative Commons Attribution-Non Commercial License \\ (http://creativecommons.org/licenses/by-nc/3.0/legalcode), which permits unrestricted use, distribution, and reproduction in any medium, \\ provided the original work is properly cited. You may not use this work for commercial purposes. \\ The electronic version of this article is the complete one and can be found at: http://fl000.com/reports/b/4/6
}

\begin{abstract}
In contrast to the development of Th I (type I T helper cells), Th I 7 and Treg (regulatory T cells), little is known of the mechanisms governing Th2 development, which is important for immunity to helminths and for us to understand the pathogenesis of allergy. A picture is emerging in which mucosal epithelial cells instruct dendritic cells to promote Th2 responses in the absence of IL-I2 (interleukin I2) production and provide instruction through thymic stromal lymphopoieitin (TSLP) or granulocytemacrophage colony stimulating factor (GM-CSF). At the same time, allergens, helminths and chemical adjuvants elicit the response of innate immune cells like basophils, which provide more polarizing cytokines and IL-4 and reinforce Th2 immunity. This unique communication between cells will only be fully appreciated if we study Th2 immunity in vivo and in a tissue-specific context, and can only be fully understood if we compare several models of Th2 immune response induction.
\end{abstract}

\section{Introduction: Th2 lymphocytes, the lesser gods of adaptive immunity}

Th2 cell immunity is something of a two-edged sword. These cells evolved to fight off parasites, but they are also responsible for allergic diseases. Recent advances in understanding Th2 immunity bring us closer to more effective treatments for allergic diseases like allergic asthma and rhinitis, atopic dermatitis and food allergy. These are clearly on the rise in western societies, and pose a significant burden on the health of millions of patients and on health expenditure.

The immune system evolved to neutralize or kill invading pathogens, while at the same time avoiding reactivity to self, harmless commensal organisms and environmental antigens like allergens. Most often, pathogens are neutralized through the effector mechanisms of innate immunity, such as the activation of complement, and phagocytosis and/or killing by macrophages, neutrophils or eosinophils. These innate responses are reinforced by adaptive immunity, in that humoral immunity facilitates complement activation and phagocytosis by innate immune cells and that particular subsets of T lymphocytes help innate effector cells through release of cytokines. $\mathrm{CD}^{+} \mathrm{T}$ helper lymphocytes are divided into broad categories based on the cytokines produced. Th1 lymphocytes produce interferon (IFN)- $\gamma$ and stimulate the phagocytosis and killing of intracellular bacteria by macrophages. Th17 lymphocytes produce IL-17, which stimulates neutrophils to kill extracellular bacteria and fungi. Th2 lymphocytes produce IL-4, IL-5 and IL-13. IL-5 stimulates the differentiation of eosinophils, which have important roles in killing helminths and other parasites, whereas IL-4 and IL-13 stimulate contraction of smooth muscle and overproduction of mucus, which helps in expulsion of helminths from the gut and lung. The IL-4 (and, to a lesser extent IL-13) produced by Th2 cells also drives the class switching of $\mathrm{B}$ cell immunoglobulin production towards immunoglobulin E. Antigen-specific IgE subsequently arms effector cells, like basophils and mast cells, that express the high affinity IgE receptor (Fc $\varepsilon$ RI, Fc $\varepsilon$ receptor I), which rapidly degranulate upon 
re-encounter with the antigen and help in parasite expulsion or resistance to reinfection [1]. Not surprisingly, therefore, Th2 immune responses are often accompanied by activated eosinophils, basophils, and mast cells, as well as goblet cell hyperplasia and functional changes to the surrounding tissues. These activation loops of innate and adaptive immunity need to be closely regulated. Naturally occurring and induced Treg dampen overt inflammatory reactions to microorganisms, and also suppress immunity to self, by suppressing the activation of innate immune cells, the antigen presenting capacity of dendritic cells and the effector function of Th1, Th2 and Th17 cells.

Despite the wealth of information and explosion of recent research on how Th1, Th17 and Treg responses are programmed, relatively less is known about the initiation of Th2 responses. Understanding Th2 immunity is important, as it is central to understanding allergic diseases. Like helminth infection, these diseases are characterized by increased production of IgE antibodies (to inhaled or ingested harmless allergens) and eosinophilic infiltration of the affected tissues. One possible contributing factor to the increase in allergies in the west is that the most commonly used adjuvant for vaccines in humans aluminum hydroxide is also a known Th2 inducer in mice and humans, so understanding its mechanism of action might have great implications for design of better adjuvants [1]. We will not describe the precise molecular mechanisms of Th2 lineage decisions during Th polarization and development, as this is the subject of several recent excellent review articles [2-4]. It has been shown that dendritic cells are at the very heart of inducing $\mathrm{T}$ cell responses; however, there has been a lot of debate about how, and even if, they are involved in Th2 response induction. Here, we will discuss the role of dendritic cells in different Th2 models and focus on the communication of dendritic cells with their neighboring epithelial cells and the cells of the innate immune response like basophils, mast cells and eosinophils.

\section{The role of dendritic cells in different Th2 models}

Dendritic cells perform a unique sentinel function in the immune response in that they recognize antigens through expression of ancient pathogen pattern recognition receptors (PRRs), such as Toll-like receptors (TLRs), NOD-like receptors, and C-type lectin receptors. These receptors will recognize motifs on virtually any pathogen, allergen, or substance. In addition, dendritic cells have been shown to be sensitive to more generic stress responses, such as oxidative stress, increased rates of protein synthesis and hypoxia, that could also signal the presence of xenobiotics, local tissue injury and disturbance of homeostasis [5,6]. Dendritic cells take up, process and present antigens on their surface, and posses the ability to migrate from the tissues to the draining lymph node. Having all these capabilities, dendritic cells are at the crossroads between innate and adaptive immunity [7].

The study of the functional importance of dendritic cells in various Th2 diseases has been greatly aided by the availability of transgenic models in which dendritic cells can be conditionally depleted or rendered functionally incapable of antigen presentation [9-12]. In one such model, in which $c d 11 c$ DTR mice were subjected to house dust mite exposure, it was shown that Th2 immunity, as measured by the early production of $\mathrm{IL}-4$ in $\mathrm{CD} 4^{+}$ $\mathrm{T}$ lymphocytes and the development of airway eosinophilia and IL-4, IL-5 and IL-13 production by mediastinal lymph node T cells, failed to develop [8]. Also, it was shown that Th2 immunity and features of Th2-dependent asthma did not develop following inhalation of the harmless protein antigen ovalbumin in the lung when dendritic cells were eliminated $[9,10]$. This dependence of Th2 immunity on dendritic cells was also seen when mice with chronic airway remodeling (typically seen in asthma of long duration) were exposed to a new allergen [16]. When dendritic cells were depleted during infection with the parasitic helminth Schistosoma mansoni, Th2 immunity failed to develop and responses skewed towards a Th1 dominated response [11]. In a more chronic model of the intestinal parasite Heligmosomoides polygyrus, Th2 effector responses in the gut were severely affected by dendritic cell depletion [12]. Finally, depletion of CD11 $\mathrm{c}^{\text {hi }}$ dendritic cells in mice exposed to ovalbumin antigen in the Th2 adjuvant alum completely abolished Th2 immunity, as measured by the induction of IgE responses and eosinophilic airway inflammation upon ovalbumin aerosol re-exposure in immunized mice [13]. It was shown that a large part of the adjuvant effects of alum were mediated by the in vivo release of the endogenous danger signal uric acid. When uric acid crystals are mixed with harmless ovalbumin and injected intraperitoneally, this also induced Th2 immunity, and this response was abolished in $c d 11 c$ DTR mice depleted of dendritic cells [14]. These experiments showed that CD11 $\mathrm{c}^{\text {hi }}$ dendritic cells are necessary for Th2 immunity. However, it has to be noted that by using the $c d 11 c$ promoter to deplete dendritic cells, there are also some off target effects. It has been shown that alveolar macrophages and a proportion CD8+ T cells and plasma cells also express CD11c and will, thereby, also be depleted by this treatment $[10,15]$. However, adoptive transfer of these affected cell types showed that the effect seen by depleting cells expressing CD11c was due to the depletion of dendritic cells [10]. 
Having established that dendritic cells are necessary for induction of Th2 immunity, we asked whether they are sufficient. When we transferred as few as 30,000 house dust mite-pulsed lung-derived dendritic cells into the lungs of naïve mice, a Th2 response to house dust mite was induced and eosinophilic airway inflammation developed upon re-exposure of the mice to house dust mite [8]. More precise studies are warranted to define with certainty whether specific subsets of dendritic cells (inflammatory dendritic cells versus subtypes of $\mathrm{CD} 24^{+} \mathrm{CD} 8 \alpha^{+} \mathrm{CD} 103^{+}$or $\mathrm{CD} 24^{-} \mathrm{CD} 11 \mathrm{~b}^{+}$conventional dendritic cells) are differentially endowed with potential to induce Th2 immunity. However, this question can be partially, yet indirectly, answered by the fact that Th2 sensitization can be induced by adoptive transfer of GMCSF cultured bone marrow dendritic cells, most closely resembling mature monocyte-derived $\mathrm{CD} 11 \mathrm{~b}^{+}$dendritic cells, but not by Flt3L cultured bone marrow-derived dendritic cells that more resemble the immature, steadystate dendritic cells resident in the lymph nodes and spleen $[14,16,18,19]$. Lung dendritic cells can be divided into several subsets [17], grossly divided into CD $11 \mathrm{c}^{+}$ conventional dendritic cells and CD11 ${ }^{\text {low }}$ plasmacytoid dendritic cells. Conventional dendritic cells can be further divided based on expression of either the myeloid marker CD11b or the integrins CD103 ( $\alpha \mathrm{E} \beta 7$ ) and langerin (CD207) [20]. During inflammation, monocyte-derived inflammatory dendritic cells are also attracted to the site of inflammation [13].

Function can also be site-dependent. In the skin and gut, $\mathrm{CD}_{103}{ }^{+}$dendritic cells are primarily involved in crosspresentation of self or foreign antigens to $\mathrm{CD}^{+} \mathrm{T}$ cells, the generation of gut-tropic effector $\mathrm{T}$ cells and the induction of Treg. In the lung, however, it has recently been shown that $\mathrm{CD}_{1} 1 \mathrm{~b}^{+}$dendritic cells were more efficient at inducing Th2 cells producing IL-4 and IL-10, whereas $\mathrm{CD}_{103}{ }^{+}$dendritic cells induced greater frequencies of $\mathrm{CD}^{+} \mathrm{T}$ cells producing IFN- $\gamma$ and IL-17A [18]. The role of plasmacytoid dendritic cells in the induction of Th2 immunity is unclear. Several experiments from several groups have shown that plasmacytoid dendritic cells dampen Th2 immunity to inhaled antigens in vivo [19-21]. However, plasmacytoid dendritic cells have been shown to activate memory Th2 cells in vitro [22]. Recently, it was shown that increased PD-L1 and PD-L2 expression in plasmacytoid dendritic cells activated Th2 effector cells [23]. The precise role of plasmacytoid dendritic cells in suppressing Th2 development in the lung is the subject of intense research. The function of plasmacytoid dendritic cells is in balance with that of conventional dendritic cells and determined by the cytokine osteopontin [24], as well as by activation of the complement system $[25,28]$.

\section{Dendritic cell-independent development of Th2 immunity}

Recent papers have proposed that basophils, rather than dendritic cells, are the true inducers of Th2 lymphocyte responses by serving as an early source for the Th2 instructive cytokine IL-4 and, at the same time, acting as antigen presenting cells [26,27]. These authors also suggested that for some antigens, like the model allergen papain or for the helminth Trichuris muris, dendritic cells were neither sufficient nor necessary for Th2 induction. These conclusions were based on the use of mice expressing MHCII exclusively from the $c d 11 c$ promoter, and reconstituted with $\mathrm{CD}^{+}{ }^{+}$wild type $\mathrm{T}$ cells. These mice poorly reconstitute MHCII expression on migratory inflammatory dendritic cells, which might explain the lack of evidence in this model for a role of dendritic cells as sufficient APCs for inducing Th2 immunity. Another caveat to these studies was the use of the MAR1 antibody to the FceRI. We, and others, have found that inflammatory dendritic cells are also depleted by this antibody $[8,28]$. Studies employing genetic strategies to deplete basophils using Cre/lox technology (mcpt8Cre mice) have found that Th2 immunity to papain and the helminth Nippostrongylus brasiliensis is unaffected in the absence of basophils, yet severely depleted when dendritic cells are genetically targeted using cd11cDTA mice [29]. Another recent study showed that in vivo basophils did not interact with antigen-specific T cells in the lymph node and that IL-4 producing basophils could only be found in the affected peripheral tissues [30]. We concur with the view of others that the most likely scenario is that basophils cooperate with dendritic cells to promote Th2 immunity, but do not necessarily have to present antigen to perform this function (Figure 1) [8,31].

\section{Direct dendritic cell - $\mathrm{T}$ cell interaction and Th2 instruction}

In the draining lymph node, dendritic cells interact with naïve Th cells and induce their differentiation. Whereas activated $\mathrm{CD} 4^{+} \mathrm{T}$ cells differentiate into the Th1 lineage in response to IL-12 provided by the dendritic cells, similar signals that initiate Th2 differentiation remain poorly characterized. Th2 differentiation is induced through the actions of the cytokine IL-4 in the absence of IL-12 production by dendritic cells. When we retrovirally overexpressed IL-12, GM-CSF cultured dendritic cells were no longer capable of inducing Th2 immunity in the lungs [32]. Others have proposed that production of IL-6 could be decisive in Th2 instruction [33-35], since IL-4 ${ }^{\mathrm{KO}}$ mice can still mount a Th2 response [36,37].

Differentiation of naïve Th cells into Th2 cells requires the upregulation of the transcription factor GATA3 [38] and requires activation of STAT-5 (through IL-2 or TSLP) and STAT-6 transcription factors [39]. GATA3 and STAT-6 
activation can be upregulated either through IL-4R signalling or Jagged-Notch signalling $[40,41]$. Notch-dependent signals have been shown to directly regulate GATA-3 expression and critically control Th cell fate in vivo $[40,42,43]$. However, it has also been suggested that Notch signals provide survival and proliferative advantages to committed Th cells rather than direct commitment to the Th cell fate [44]. Nonetheless, recently Jagged 1 , and not Jagged2, expression on dendritic cells has been shown to be critical for IL-4 induction and the promotion of allergic responses. Where exactly the STAT- 5 activating signal comes from is less well understood. Dendritic cells have been shown to produce IL-2 and TSLP, but these could also be produced by $\mathrm{T}$ cells in an autocrine manner upon $\mathrm{T}$ cell activation [45].

Besides the expression of Jagged and production of cytokines, other surface markers on dendritic cells can

Figure I. A complex cellular network underlies the initiation of type 2 immune responses

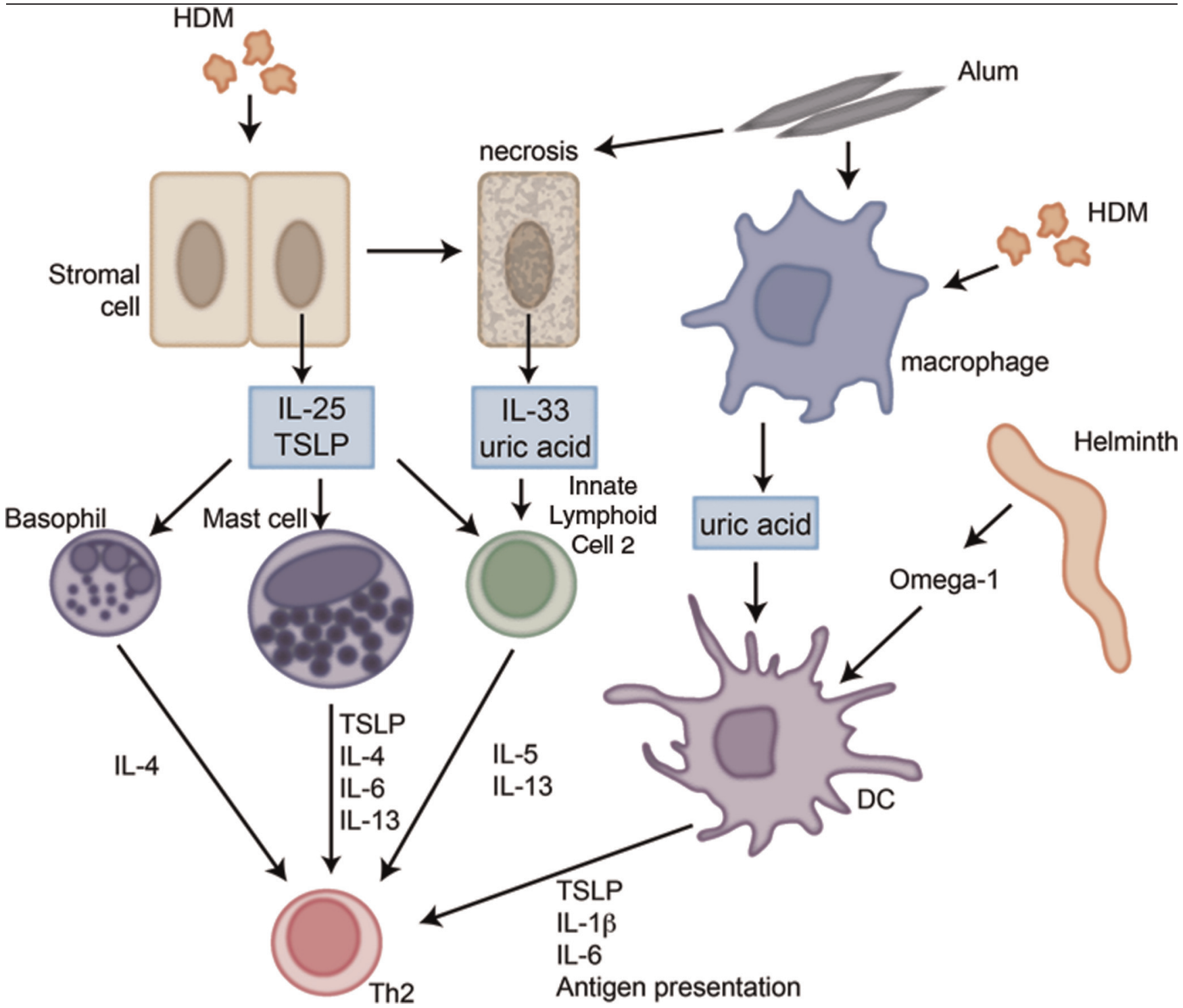

Antigen stimulation leads to TSLP (thymic stromal lymphopoietin) or IL(interleukin)-25 production from stromal cells, which subsequently stimulates type 2 effector cytokine expression from various cell types, including innate lymphoid cells, basophils and mast cells. Alternatively, IL-33, which induces many of the features similar to IL-25 and TSLP, is released as an active form from necrotic cells and acts as an alarmin. Besides IL-33, uric acid is released from dying cells and produced by macrophages after alum or house dust mite stimulation. In addition, certain antigens such as Omega-I from the helminth S. mansoni prime dendritic cells, so that they guide CD4 ${ }^{+} \mathrm{T}$ cells towards a Th(T helper cells) 2 response. Abbreviations: $\mathrm{DC}$, dendritic cell; HDM, house dust mite; IL, interleukin; Th, T helper cell; TSLP, thymic stromal lymphopoietin. 
influence Th2 differentiation. The expression of OX40L on dendritic cells has also been shown to be required for optimal Th2 priming [46-48]. The expression of OX40L on dendritic cells is dependent upon signalling through CD40 $[47,49,50]$. Furthermore, CD40 expression itself is important for Th2 induction as $\mathrm{CD} 40^{-/}$dendritic cells were incapable of inducing Th2 responses to helminth antigens [50]. CD40 interacts with CD154 on T cells and this also seems to be necessary for Th2 immunity. When mice deficient in CD154 were infected with $S$. mansoni helminths, they did not induce Th2 immunity and suffered from severe morbidity and mortality [51]. More confirmation is provided by the observation that $S$. mansoni egg preparations prime Th2 cells via the functional modulation of dendritic cells $[46,52]$. Dendritic cells exposed to parasitic helminth-derived antigens, including SEA, are distinguished by their low production of IL-12, which is thought to be a prerequisite for their Th2-inducing capacity [53]. The omega-1 antigen from Schistosoma applied to dendritic cells in vitro stimulates Th2 development independent of IL-4R $\alpha$ signalling in vivo [54].

\section{Interaction of dendritic cells with epithelial cells leads to polarization of dendritic cells}

Stromal cells have been shown to be important in instructing dendritic cell behavior, particularly in mucosal tissues where epithelial cells represent the first line barrier to the outside world, making them candidates for orchestrating immune responses [55-58]. Some supporting evidence for this comes from the finding that certain dendritic cells are located just below the epithelial lining in the lung, making them easily assessable for epithelial cell-derived factors (Figure 2) [17]. Indeed, chemokines like CCL2 and CCL20 that attract immature dendritic cells and their precursors are produced by airway epithelial cells exposed to Th2 stimuli like house dust mite [59-62]. In response to inhaled allergens, airway epithelial cells secrete a variety of cytokines (GM-CSF, TSLP, IL-25, IL-33, and IL-1 family members), which contribute to dendritic cell maturation and drive them into a Th2-activating mode $[59,63]$.

One example of this was shown in mice overexpressing GM-CSF, who showed a break of tolerance to the inhaled harmless antigen ovalbumin, and developed a strong Th2 allergic airway inflammation driven by mature dendritic cells [64]. Also, in a mouse model of house dust miteinduced asthma, GM-CSF was shown to be necessary (but not sufficient) for proper Th2 responses [65-68].

Another well-described Th2-inducing cytokine produced by epithelial cells (but also by mast cells and dendritic cells themselves under inflammatory conditions) is TSLP $[45,59,69]$. Initially, TSLP was found to potently enhance the maturation of CD11 $\mathrm{c}^{+}$ dendritic cells, and TSLP-primed dendritic cells were shown to promote Th2 differentiation. TSLP was reported to exert its Th2-promoting properties through a dendritic cell-mediated pathway that involved induction of OX40L [59,70-72]. Mice overexpressing TSLP in the lung epithelium had increased asthma features [73], whereas blockade of the TSLP-R inhibited key features of allergic asthma [74]. Besides the effects on dendritic cells, TSLP also influences the function of mast cells and basophils, cell types involved in Th2 responses, by acting as a growth factor $[75,76]$. In specific helminth infections, like $H$. polygyrus, $N$. brasiliensis and $S$. mansoni, TSLP plays a role in the clearance of worms induced by Th2 immunity [77]. While, TSLP is not necessary for clearing all helminth infections, for Trichuris muris it was shown to be indispensible; this could be because T. muris is less efficient in Th2 induction and more potent than other helminths in triggering Th1 responses [3].

IL-25 (also known as IL-17E) was initially reported as a Th2 cell-derived cytokine, but it can also be produced by basophils [72] and airway epithelial cells in response to allergens and respiratory viruses $[78,79]$. In mice, overexpression of IL-25 in lung epithelial cells led to allergic inflammation, likely due to the capacity of IL-25 to activate dendritic cells to induce Th2 responses [80]. Injection of neutralizing anti-IL-25 antibodies was able to strongly reduce allergic airway inflammation and airway remodelling [78].

The last group of Th2 instructive cytokines discussed here are the IL-1 family members. Some IL- 1 family members are produced as pro-cytokines that require cleavage by caspase-1 through the inflammasome activation to be released [81]. IL- $1 \alpha$ and IL-1 $\beta$ both bind to the IL- 1 receptor 1 (IL-1RI), which is present on almost all cell types, including structural cells such as airway epithelial cells $[82,83]$. IL- $1 \beta$ is released from cultured airway epithelial cells following protease allergen exposure and enhances the release of the dendritic cell-attracting chemokine CCL20, and of the dendritic cell maturation cytokines TSLP and GM-CSF [84,85]. IL-1R signalling involves the adaptor molecule MyD88, also found downstream of several TLRs. Interestingly, house dust mite-induced $\mathrm{Th} 2$ responses in the lung were found to be strongly reduced in MyD88 $\%$ mice [86]; however, pathology induced by $S$. mansoni infection was unaltered [87]. Also, dendritic cells have been shown to express ST2, the receptor for the IL-1 family member IL-33. This cytokine is expressed in airway epithelial cells where it is constitutively stored in nuclei. Its location is unexpected, 
Figure 2. Interactions between airway epithelial cells and dendritic cells

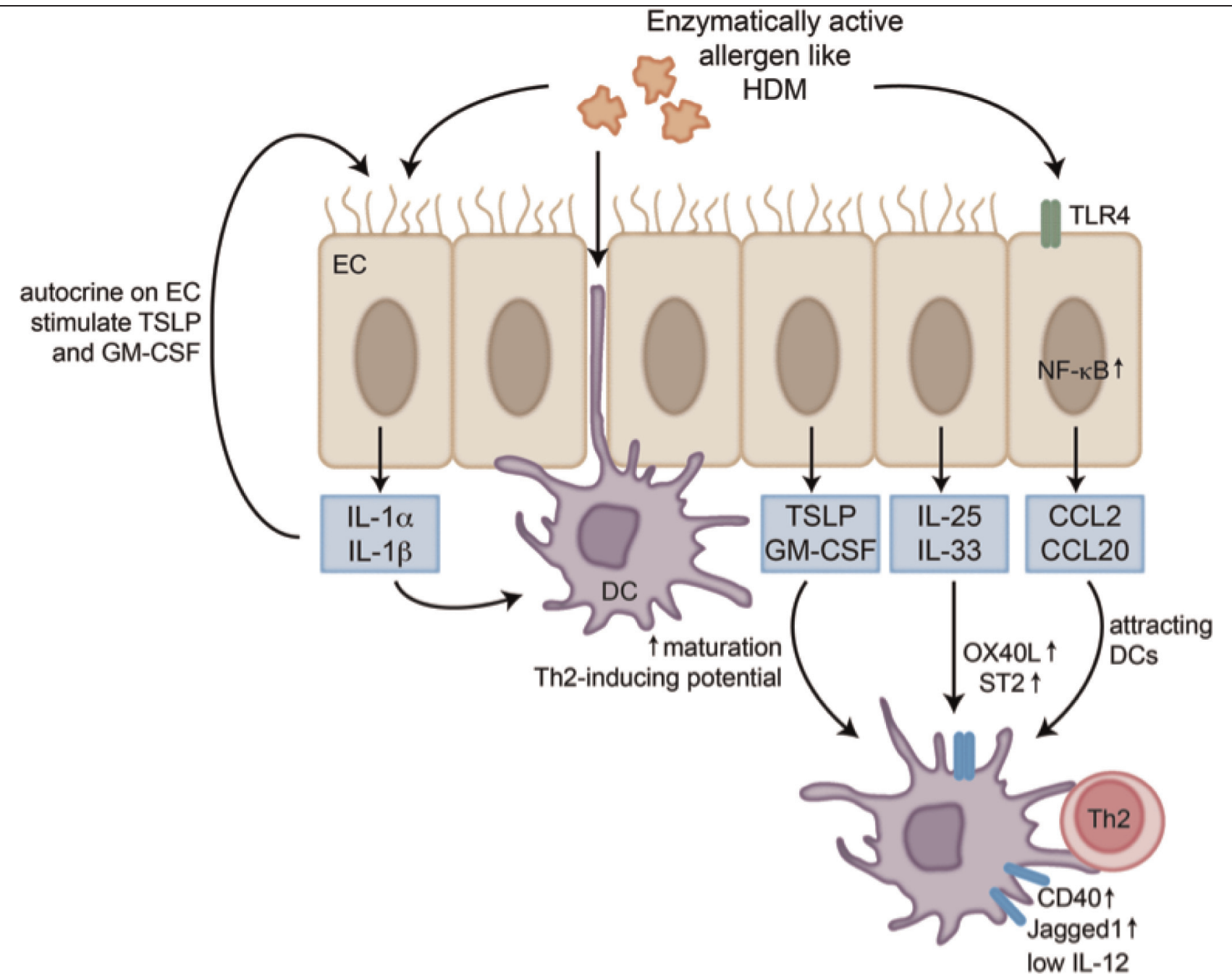

Dendritic cells (DCs) sample the airway lumen by forming dendritic extensions between epithelial cells. Enzymatically active allergens, like house dust mite can stimulate airway epithelial cells, via TLR(toll-like receptor) 4 followed by NF- $\kappa B$ (nuclear factor- $\kappa B$ ) activation, to produce chemokines and cytokines that attract and activate DCs. Certain cytokines, like IL(interleukin)-25 and IL-33 will lead to the upregulation of OX40L, CD40 and ST2, which will lead to polarization of $\mathrm{CD}^{+}$T cells towards a Th2 phenotype. Other cytokines like IL-I $\alpha$ and $\beta$ activate DCs, but also have a positive autocrine feedback on epithelial cells and further stimulate the production of TSLP and GM-CSF. Abbreviations: DC, dendritic cell; EC, epithelial cell; GM-CSF, granulocyte-macrophage colony stimulating factor; HDM, house dust mite; IL, interleukin; NF- $\kappa B$, nuclear factor- $k B$; TLR, toll-like receptor; TSLP, thymic stromal lymphopoietin.

and how it is released into the extracellular environment remains unclear. It has been postulated, however, that IL-33 might act as an alarmin in case of allergen exposure [88]. Dendritic cells exposed to IL-33 increased their expression of maturation markers, such as CD40 and OX40L and, thereby, became very potent at inducing Th2 responses $[89,90]$. Both IL-33 and IL-25 have also been shown to induce an allergic phenotype or helminth clearance independent of Th2 lymphocytes [91,92]. In Rag deficient mice, which lack $\mathrm{T}$ and $\mathrm{B}$ cells, innate lymphoid cells producing IL-5 and IL-13 are induced by IL-25 or IL-33 [93].
PRR expression by radioresistant stromal cells determines Th2 immune response induction by dendritic cells

Several groups have used radiation chimeric models to study the relative importance of PRRs of the TLR or NLR (NOD-like receptors) family to induction of Th2 immunity. Using chimeric Tlr $4^{--}$animals, we and others have demonstrated that the expression of TLR4 on epithelial cells is crucial in inducing dendritic cell recruitment and intramucosal migratory behaviour in response to LPS and house dust mite [59,94]. In response to house dust mite inhalation, TSLP, GM-CSF, IL-25 and IL-33 are made in an epithelial TLR4-dependent manner [59]. TLR4 is triggered 
by endotoxin found inside the house dust mite extract and this is facilitated by the house dust mite allergen Der p 2, which behaves like the MD2 chaperone and is important for TLR4 activation [95]. This seems to be a common theme, as many natural and synthetic allergens like cat allergen Fel d 1 and nickel also trigger TLR4. Although some helminths like $S$. mansoni activate dendritic cells via TLR2 and TLR3, these receptors are dispensable to control infection and pathology [96].

In a recent study, it was shown that Th2 immunity, induced by injection of ovalbumin with agonists of the NLR receptors NOD1 and NOD2, was also dependent on stromal expression of these receptors, acting to induce the systemic production of TSLP and induction of dendritic cell maturation [97]. The precise role of other NLRs like NLRP3 (involved in the formation of the IL-1 and IL-18 inducing inflammasome) in Th2 immunity to natural allergens and alum is very controversial. Initially, it was proposed that Th2 immunity to alum was completely abolished in the absence of Nlrp3 [98], but others have refuted this idea $[14,99,100]$, and it has long been known that alum-induced Th2 asthma models were IL-1R and MyD88-independent [101]. Papers show either an abrogation of alum response in the absence of NLRP3 $[98,102]$, no need for NLRP3 $[103,104]$, or a selective need for NLRP3 [105]. The differences found by the different groups could be due to the type of alum and ovalbumin used and/or mouse strain background.

For natural Th2 immunity to house dust mite in the lung, we and others have found the NLRP3 inflammasome to be irrelevant [14], whereas others have found a lack of the NLRP3 inflammasome to cause a deficiency in Th2 induction when house dust mite was applied to the skin [106]. These studies have certainly aroused interest in inflammasomes, and it remains to be determined how other NLRs are involved in Th2 immune responses to allergens and helminths. Finally, stromal cells (like epithelial cells, and also dendritic cells) express C-type lectin receptors like dectin-2 that have been shown to be involved in Th2 immune responses to house dust mite allergen [107]. Signalling through these receptors often involves the spleen tyrosine kinase pathway that increasingly appears to be crucial for Th2 development $[14,34]$, through, as yet, unidentified mechanisms.

\section{Conclusion}

Recent advances are starting to dissect the mechanisms of Th2 development, and a picture is emerging that mucosal epithelial cells instruct dendritic cells to promote Th2 responses by inducing their activation in the absence of IL-12 production. At the same time Th2 stimulates innate immune cells like basophils, mast cells and innate lymphoid cell 2 to produce more polarizing cytokines and ILl-4, which reinforce Th2 immunity. This unique communication network of cells will only be fully appreciated if we study Th2 immunity in vivo in a tissue specific context, and if we compare several models of Th2 immune response induction, like helminth infection, allergen exposure and chemical adjuvants. Given the role of dendritic cells in promoting allergy, greater understanding may yield new targets for prevention and treatment.

\section{Abbreviations}

GM-CSF, granulocyte-macrophage colony stimulating factor; IFN, interferon; IL, interleukin; NLR, NOD-like receptors; PRR, pattern recognition receptor; Th, Thelper cell; TLR, toll-like receptor; Treg, regulatory T cell; TSLP, thymic stromal lymphopoietin.

\section{Competing Interests}

The authors declare that they have no competing interests.

\section{References}

I. Lambrecht BN, Kool M, Willart MAM, Hammad H: Mechanism of action of clinically approved adjuvants. Curr. Opin. Immunol 2009, $21: 23-9$.

2. O'Shea JJ, Paul WE: Mechanisms underlying lineage commitment and plasticity of helper CD4+ T cells. Science 2010, 327:1098-102.

FI000 Factor 6

Evaluated by Bart Lambrecht 17 Feb 2012

3. Paul WE, Zhu J: How are $\mathbf{T}(\mathbf{H}) 2$-type immune responses initiated and amplified? Nat. Rev. Immunol 2010, 10:225-35.

FI000 Factor 6

Evaluated by Bart Lambrecht 17 Feb 2012

4. Pulendran B, Tang H, Manicassamy S: Programming dendritic cells to induce $\mathbf{T}(\mathbf{H}) 2$ and tolerogenic responses. Nat. Immunol 2010 , I I:647-55.

FI000 Factor 6

Evaluated by Bart Lambrecht 17 Feb 2012

5. Ohtani T, Nakagawa S, Kurosawa M, Mizuashi M, Ozawa M, Aiba S: Cellular basis of the role of diesel exhaust particles in inducing Th2-dominant response. J. Immunol 2005, I 74:24I2-9.

FI000 Factor 6

Evaluated by Bart Lambrecht 17 Feb 2012

6. Todd DJ, Lee A, Glimcher LH: The endoplasmic reticulum stress response in immunity and autoimmunity. Nat. Rev. Immunol 2008, 8:663-74.

FI000 Factor 6

Evaluated by Bart Lambrecht 17 Feb 2012

7. Banchereau J, Steinman RM: Dendritic cells and the control of immunity. Nature 1998, 392:245-52.

8. Hammad H, Plantinga M, Deswarte $K$, Pouliot P, Willart MAM, Kool M, Muskens F, Lambrecht BN: Inflammatory dendritic cellsnot basophils-are necessary and sufficient for induction of 
Th2 immunity to inhaled house dust mite allergen. J. Exp. Med 2010, 207:2097-III.

\section{FI000 Factor II}

Evaluated by Achsah Keegan and Nicola Heller 2I Sep 2010, Minoru Fukuda and Xingfeng Bao 06 Dec 2010, Marc A Williams 17 Dec 2010

9. Lambrecht BN, Salomon B, Klatzmann D, Pauwels RA: Dendritic cells are required for the development of chronic eosinophilic airway inflammation in response to inhaled antigen in sensitized mice. J. Immunol 1998, I 60:4090-7.

10. van Rijt LS, Jung S, Kleinjan A, Vos N, Willart M, Duez C, Hoogsteden HC, Lambrecht BN: In vivo depletion of lung CDI I c+ dendritic cells during allergen challenge abrogates the characteristic features of asthma. J. Exp. Med 2005, 20I:98I-91.

FI000 Factor 8

Evaluated by Giorgio Berton 21 Apr 2005

II. van Rijt LS, Vos N, Willart M, Muskens F, Tak PP, van der Horst C, Hoogsteden HC, Lambrecht BN: Persistent activation of dendritic cells after resolution of allergic airway inflammation breaks tolerance to inhaled allergens in mice. Am. J. Respir. Crit. Care Med 201 I, I 84:303-II.

12. Smith KA, Hochweller K, Hämmerling GJ, Boon L, MacDonald AS, Maizels RM: Chronic helminth infection promotes immune regulation in vivo through dominance of CDIIcloCDI03dendritic cells. J. Immunol 201 I, I86:7098-109.

13. Kool M, Soullié T, van Nimwegen M, Willart MAM, Muskens F, Jung S, Hoogsteden HC, Hammad H, Lambrecht BN: Alum adjuvant boosts adaptive immunity by inducing uric acid and activating inflammatory dendritic cells. J. Exp. Med 2008, 205:869-82.

FI000 Factor 8

Evaluated by Eric Denkers 28 Mar 2008

14. Kool M, Willart MAM, van Nimwegen M, Bergen I, Pouliot P, Virchow JC, Rogers N, Osorio F, Reis E, Sousa C, Hammad H, Lambrecht BN: An unexpected role for uric acid as an inducer of Thelper 2 cell immunity to inhaled antigens and inflammatory mediator of allergic asthma. Immunity 20II, 34:527-40.

\section{FI000 Factor 6}

Evaluated by Booki Min 10 Jun 2011

15. Jung S, Unutmaz D, Wong P, Sano G, de los Santos K, Sparwasser T, Wu S, Vuthoori S, Ko K, Zavala F, Pamer EG, Littman DR, Lang RA: In vivo depletion of $C D I I c+$ dendritic cells abrogates priming of CD8+ $\mathrm{T}$ cells by exogenous cell-associated antigens. Immunity 2002, I 7:21।-20.

\section{FI000 Factor 7}

Evaluated by Peter Jensen 13 Sep 2002, John Cambier 04 Dec 2002

16. Lambrecht BN, Veerman $M$ de, Coyle AJ, Gutierrez-Ramos JC, Thielemans K, Pauwels RA: Myeloid dendritic cells induce Th2 responses to inhaled antigen, leading to eosinophilic airway inflammation. J. Clin. Invest 2000, 106:55I-9.

17. Plantinga $\mathrm{M}$, Hammad $\mathrm{H}$, Lambrecht $\mathrm{BN}$ : Origin and functional specializations of DC subsets in the lung. Eur. J. Immunol 2010 , 40:21 12-8.

18. Furuhashi K, Suda T, Hasegawa H, Suzuki $Y$, Hashimoto D, Enomoto $N$, Fujisawa $T$, Nakamura $Y$, Inui $N$, Shibata $K$, Nakamura H, Chida K: Mouse Lung CDI03+ and CDIIbhigh dendritic cells preferentially induce distinct $C D 4+\mathrm{T}$ cell responses. Am. J. Respir. Cell Mol. Biol $20 \mathrm{II}$.

19. Heer HJ de, Hammad H, Soullié T, Hijdra D, Vos N, Willart MAM, Hoogsteden HC, Lambrecht BN: Essential role of lung plasmacytoid dendritic cells in preventing asthmatic reactions to harmless inhaled antigen. J. Exp. Med 2004, 200:89-98.

FI000 Factor II

Evaluated by Ann Hill 13 Aug 2004, Marsha Wills-Karp 23 Sep 2004

20. Kool M, van Nimwegen M, Willart MAM, Muskens F, Boon L, Smit JJ, Coyle A, Clausen BE, Hoogsteden HC, Lambrecht BN, Hammad H: An anti-inflammatory role for plasmacytoid dendritic cells in allergic airway inflammation. I. Immunol 2009, 183:1074-82.

21. Smit JJ, Lindell DM, Boon L, Kool M, Lambrecht BN, Lukacs NW: The balance between plasmacytoid DC versus conventional DC determines pulmonary immunity to virus infections. PLOS ONE 2008, 3:e 1720.

22. Farkas L, Kvale EO, Johansen F, Jahnsen FL, Lund-Johansen F: Plasmacytoid dendritic cells activate allergen-specific TH2 memory cells: modulation by $\mathbf{C p G}$ oligodeoxynucleotides. J. Allergy Clin. Immunol 2004, I | 4:436-43.

23. Zhang X, Lewkowich IP, Köhl G, Clark JR, Wills-Karp M, Köhl J: A protective role for $\mathrm{C5a}$ in the development of allergic asthma associated with altered levels of B7-HI and B7-DC on plasmacytoid dendritic cells. J. Immunol 2009, I 82:5 I 23-30.

24. Xanthou G, Alissafi T, Semitekolou M, Simoes DCM, Economidou E, Gaga M, Lambrecht BN, Lloyd CM, Panoutsakopoulou V: Osteopontin has a crucial role in allergic airway disease through regulation of dendritic cell subsets. Nat. Med 2007, I3:570-8.

25. Köhl J, Baelder R, Lewkowich IP, Pandey MK, Hawlisch H, Wang L, Best J, Herman NS, Sproles AA, Zwirner J, Whitsett JA, Gerard C, Sfyroera G, Lambris JD, Wills-Karp M: A regulatory role for the C5a anaphylatoxin in type $\mathbf{2}$ immunity in asthma. J. Clin. Invest 2006, I I 6:783-96.

26. Perrigoue JG, Saenz SA, Siracusa MC, Allenspach EJ, Taylor BC, Giacomin PR, Nair MG, Du Y, Zaph C, van Rooijen N, Comeau MR, Pearce EJ, Laufer TM, Artis D: MHC class II-dependent basophilCD4+ T cell interactions promote $\mathbf{T}(\mathrm{H}) 2$ cytokine-dependent immunity. Nat. Immunol 2009, 10:697-705.

FI000 Factor 20

Evaluated by Dale Umetsu 0I Jun 2009, Eric Denkers 03 Jun 2009, Richard Grencis 17 Jun 2009, Caetano Reis e Sousa 02 Jul 2009, Thomas Wynn 23 Jul 2009, Jonathan Lamb 09 Sep 2009, Mark Bix 26 Nov 2009

27. Sokol CL, Chu N, Yu S, Nish SA, Laufer TM, Medzhitov R: Basophils function as antigen-presenting cells for an allergen-induced $T$ helper type 2 response. Nat. Immunol 2009, 10:7| 3-20.

FI000 Factor 20

Evaluated by Eric Denkers 03 Jun 2009, Shinsuke Taki 04 Jun 2009, Kiyoshi Takeda 12 Jun 2009, Richard Grencis 17 Jun 2009, Caetano Reis e Sousa 02 Jul 2009, Thomas Wynn 23 Jul 2009, Mark Bix 26 Nov 2009

28. Grayson $M H$, Cheung $D$, Rohlfing $M M$, Kitchens $R$, Spiegel DE, Tucker J, Battaile JT, Alevy Y, Le Yan, Agapov E, Kim EY, Holtzman MJ: Induction of high-affinity IgE receptor on lung dendritic cells during viral infection leads to mucous cell metaplasia. J. Exp. Med 2007, 204:2759-69.

FI000 Factor 6

Evaluated by Marc Rothenberg 03 Dec 2007

29. Ohnmacht C, Schwartz C, Panzer M, Schiedewitz I, Naumann R, Voehringer D: Basophils orchestrate chronic allergic dermatitis and protective immunity against helminths. Immunity 2010 , 33:364-74.

\section{FI000 Factor 13}

Evaluated by Hilde Cheroutre and Daniel Mucida 16 Sep 2010, Richard L Stevens 04 Oct 2010 , Rick Maizels and James Hewitson I4 Oct 2010, Troy Randall, Luz Garcia-Hernandez and Javier RangelMoreno 10 Feb 2011, Avinash Bhandoola 18 Feb 2011

30. Sullivan BM, Liang $H$, Bando JK, Wu D, Cheng LE, McKerrow JK, Allen CDC, Locksley RM: Genetic analysis of basophil function in vivo. Nat. Immunol 20I I, I 2:527-35

FI000 Factor 10

Evaluated by Shinsuke Taki 16 May 201I, Richard Grencis 18 May 2011

3I. Tang H, Cao W, Kasturi SP, Ravindran R, Nakaya HI, Kundu K, Murthy N, Kepler TB, Malissen B, Pulendran B: The T helper type 2 response to cysteine proteases requires dendritic 
cell-basophil cooperation via ROS-mediated signaling. Nat. Immunol 2010, I I:608-17.

\section{FI000 Factor II}

Evaluated by Shinsuke Taki 27 May 2010, Juan Rivera and Nicolas Charles 16 Jul 2010, Bart Lambrecht 17 Feb 2012

32. Kuipers $H$, Heirman C, Hijdra D, Muskens F, Willart M, van Meirvenne S, Thielemans K, Hoogsteden HC, Lambrecht BN: Dendritic cells retrovirally overexpressing IL-I 2 induce strong ThI responses to inhaled antigen in the lung but fail to revert established Th2 sensitization. J. Leukoc. Biol 2004, 76:1028-38.

33. Dodge IL, Carr MW, Cernadas M, Brenner MB: IL-6 production by pulmonary dendritic cells impedes ThI immune responses. J. Immunol 2003, I 70:4457-64

34. Krishnamoorthy $N$, Oriss TB, Paglia $M$, Fei $M$, Yarlagadda $M$, Vanhaesebroeck B, Ray A, Ray P: Activation of c-Kit in dendritic cells regulates $\mathbf{T}$ helper cell differentiation and allergic asthma. Nat. Med 2008, 14:565-73.

35. Rincón M, Anguita J, Nakamura T, Fikrig E, Flavell RA: Interleukin (IL)-6 directs the differentiation of IL-4-producing CD4+ T cells. J. Exp. Med 1997, I 85:46I-9.

36. Brewer JM, Conacher M, Hunter CA, Mohrs M, Brombacher F, Alexander J: Aluminium hydroxide adjuvant initiates strong antigen-specific Th2 responses in the absence of IL-4- or ILI3-mediated signaling. J. Immunol 1999, I63:6448-54.

37. Okahashi N, Yamamoto M, Vancott JL, Chatfield SN, Roberts M, Bluethmann H, Hiroi T, Kiyono H, McGhee JR: Oral immunization of interleukin-4 (IL-4) knockout mice with a recombinant Salmonella strain or cholera toxin reveals that CD4+ Th2 cells producing IL-6 and IL- 10 are associated with mucosal immunoglobulin A responses. Infect. Immun 1996, 64:1516-25.

38. Zheng W, Flavell RA: The transcription factor GATA-3 is necessary and sufficient for Th2 cytokine gene expression in CD4 T cells. Cell 1997, 89:587-96.

FI000 Factor 6

Evaluated by Bart Lambrecht 17 Feb 2012

39. Zhu J, Guo L, Min B, Watson Cl, Hu-Li J, Young HA, Tsichlis PN, Paul WE: Growth factor independent-I induced by IL-4 regulates Th2 cell proliferation. Immunity 2002, 16:733-44.

FI000 Factor 10

Evaluated by Dan Conrad 14 Jun 2002

40. Amsen D, Antov A, Jankovic D, Sher A, Radtke F, Souabni A, Busslinger $M$, McCright $B$, Gridley T, Flavell RA: Direct regulation of Gata3 expression determines the $T$ helper differentiation potential of Notch. Immunity 2007, 27:89-99.

FI000 Factor 6

Evaluated by Bart Lambrecht 17 Feb 2012

4I. Seki N, Miyazaki M, Suzuki W, Hayashi K, Arima K, Myburgh E, Izuhara K, Brombacher F, Kubo M: IL-4-induced GATA-3 expression is a time-restricted instruction switch for Th2 cell differentiation. J. Immunol 2004, I 72:6I58-66.

FI000 Factor 6

Evaluated by Mark Bix 17 May 2004

42. Amsen D, Blander JM, Lee GR, Tanigaki K, Honjo T, Flavell RA: Instruction of distinct CD4 T helper cell fates by different notch ligands on antigen-presenting cells. Cell 2004, | | 7:5 |5-26.

FI000 Factor 18

Evaluated by David Chaplin 24 May 2004, Chen Dong 03 Jun 2004, Warren Pear 16 Jul 2004, Raphael Kopan 23 Jul 2004, Alan Houghton 27 Jul 2004

43. Fang TC, Yashiro-Ohtani Y, Del Bianco C, Knoblock DM, Blacklow SC, Pear WS: Notch directly regulates Gata3 expression during $\mathbf{T}$ helper $\mathbf{2}$ cell differentiation. Immunity 2007, 27: $100-10$.
44. Ong C, Sedy JR, Murphy KM, Kopan R: Notch and presenilin regulate cellular expansion and cytokine secretion but cannot instruct ThI/Th2 fate acquisition. PLOS ONE 2008, 3: e2823.

45. Kashyap M, Rochman Y, Spolski R, Samsel L, Leonard WJ: Thymic stromal lymphopoietin is produced by dendritic cells. J. Immunol 20II, I87:|207-II.

FI000 Factor 6

Evaluated by Elizabeth Kelly and Jim Stahl 06 Dec 201I

46. Jong EC de, Vieira PL, Kalinski P, Schuitemaker JHN, Tanaka Y, Wierenga EA, Yazdanbakhsh M, Kapsenberg ML: Microbial compounds selectively induce ThI cell-promoting or Th2 cellpromoting dendritic cells in vitro with diverse th cell-polarizing signals. J. Immunol 2002, I68: I704-9.

FI000 Factor 6

Evaluated by Bart Lambrecht 17 Feb 2012

47. Jenkins SJ, Perona-Wright G, Worsley AGF, Ishii N, MacDonald AS: Dendritic cell expression of $O \times 40$ ligand acts as a costimulatory, not polarizing, signal for optimal Th2 priming and memory induction in vivo. J. Immunol 2007, I79:35I5-23.

FI000 Factor 6

Evaluated by Bart Lambrecht 17 Feb 2012

48. Wang Y, Liu Y: Thymic stromal lymphopoietin, OX40-ligand, and interleukin-25 in allergic responses. Clin. Exp. Allergy 2009, 39:798-806.

FI000 Factor 6

Evaluated by Bart Lambrecht 17 Feb 2012

49. Kashiwakura J, Yokoi H, Saito H, Okayama Y: T cell proliferation by direct cross-talk between $\mathrm{OX} 40$ ligand on human mast cells and OX40 on human $T$ cells: comparison of gene expression profiles between human tonsillar and lungcultured mast cells. J. Immunol 2004, I73:5247-57.

FI000 Factor 6

Evaluated by Bart Lambrecht 17 Feb 2012

50. MacDonald AS, Straw AD, Dalton NM, Pearce EJ: Cutting edge: Th2 response induction by dendritic cells: a role for CD40. J. Immunol 2002, 168:537-40.

FI000 Factor 8

Evaluated by Thomas Wynn 30 Jan 2002

5I. MacDonald AS, Patton EA, La Flamme AC, Araujo MI, Huxtable CR, Bauman B, Pearce El: Impaired Th2 development and increased mortality during Schistosoma mansoni infection in the absence of CD40/CDI54 interaction. J. Immunol 2002, I 68:4643-9.

FI000 Factor 6

Evaluated by Bart Lambrecht 17 Feb 2012

52. MacDonald AS, Straw AD, Bauman B, Pearce EJ: CD8- dendritic cell activation status plays an integral role in influencing Th2 response development. J. Immunol 200I, I67:1982-8.

FI000 Factor 8

Evaluated by Thomas Wynn 30 Nov 200I

53. Jankovic D, Kullberg MC, Caspar P, Sher A: Parasite-induced Th2 polarization is associated with down-regulated dendritic cell responsiveness to ThI stimuli and a transient delay in $T$ lymphocyte cycling. J. Immunol 2004, I 73:24I9-27.

FI000 Factor6

Evaluated by Bart Lambrecht 17 Feb 2012

54. Everts B, Perona-Wright G, Smits $\mathrm{HH}$, Hokke $\mathrm{CH}$, van der Ham AJ, Fitzsimmons CM, Doenhoff MJ, van der Bosch J, Mohrs K, Haas H, Mohrs M, Yazdanbakhsh M, Schramm G: Omega-I, a glycoprotein 
secreted by Schistosoma mansoni eggs, drives Th2 responses. J. Exp. Med 2009, 206:1673-80.

FI000 Factor 6

Evaluated by Bart Lambrecht 17 Feb 2012

55. Chieppa M, Rescigno M, Huang AYC, Germain RN: Dynamic imaging of dendritic cell extension into the small bowel lumen in response to epithelial cell TLR engagement. J. Exp. Med 2006, 203:2841-52.

FI000 Factor 8

Evaluated by David Alpers 12 Apr 2007

56. Hammad H, Lambrecht BN: Dendritic cells and airway epithelial cells at the interface between innate and adaptive immune responses. Allergy 201 I, 66:579-87.

57. Lambrecht $\mathrm{BN}, \mathrm{Hammad} \mathrm{H}$ : The role of dendritic and epithelial cells as master regulators of allergic airway inflammation. Lancet 2010, 376:835-43.

58. Nolte MA, Leibundgut-Landmann $S$, Joffre $O$, Reis $E$, Sousa C: Dendritic cell quiescence during systemic inflammation driven by LPS stimulation of radioresistant cells in vivo. J. Exp. Med 2007, 204:1487-501.

59. Hammad H, Chieppa M, Perros F, Willart MA, Germain RN, Lambrecht $\mathrm{BN}$ : House dust mite allergen induces asthma via Toll-like receptor 4 triggering of airway structural cells. Nat. Med 2009, I5:410-6.

FI000 Factor 10

Evaluated by John Kyriakis I4 Apr 2009, Achsah Keegan 05 Jun 2009

60. Nathan AT, Peterson EA, Chakir J, Wills-Karp M: Innate immune responses of airway epithelium to house dust mite are mediated through beta-glucan-dependent pathways. J. Allergy Clin. Immunol 2009, I 23:612-8.

FI000 Factor 6

Evaluated by Bart Lambrecht 17 Feb 2012

6I. Pichavant M, Charbonnier A, Taront S, Brichet A, Wallaert B, Pestel J, Tonnel A, Gosset P: Asthmatic bronchial epithelium activated by the proteolytic allergen Der $p$ I increases selective dendritic cell recruitment. J. Allergy Clin. Immunol 2005, I I 5:77I-8.

FI000 Factor 6

Evaluated by Bart Lambrecht 17 Feb 2012

62. Wada K, Matsuwaki $\mathrm{Y}$, Moriyama H, Kita $\mathrm{H}$ : Cockroach induces inflammatory responses through protease-dependent pathways. Int. Arch. Allergy Immunol 201 I, I55(Suppl I): I35-4I.

FI000 Factor 6

Evaluated by Bart Lambrecht 17 Feb 2012

63. Eiwegger T, Akdis CA: IL-33 links tissue cells, dendritic cells and Th2 cell development in a mouse model of asthma. Eur. J. Immunol 20II, 4I:I535-8.

FI000 Factor 6

Evaluated by Bart Lambrecht 17 Feb 2012

64. Stämpfli MR, Wiley RE, Neigh GS, Gajewska BU, Lei XF, Snider DP, Xing Z, Jordana M: GM-CSF transgene expression in the airway allows aerosolized ovalbumin to induce allergic sensitization in mice. J. Clin. Invest 1998, 102:1704-14.

FI000 Factor 6

Evaluated by Bart Lambrecht 17 Feb 2012

65. Cates EC, Fattouh R, Wattie J, Inman MD, Goncharova S, Coyle AJ, Gutierrez-Ramos J, Jordana M: Intranasal exposure of mice to house dust mite elicits allergic airway inflammation via a GMCSF-mediated mechanism. J. Immunol 2004, I 73:6384-92.

FI000 Factor 6

Evaluated by Bart Lambrecht 17 Feb 2012

66. Cates EC, Gajewska BU, Goncharova S, Alvarez D, Fattouh R, Coyle AJ, Gutierrez-Ramos J, Jordana M: Effect of GM-CSF on immune, inflammatory, and clinical responses to ragweed in a novel mouse model of mucosal sensitization. J. Allergy Clin. Immunol 2003, I I I:1076-86.

FI000 Factor 6

Evaluated by Bart Lambrecht 17 Feb 2012

67. Fattouh R, Pouladi MA, Alvarez D, Johnson JR, Walker TD, Goncharova S, Inman MD, Jordana M: House dust mite facilitates ovalbumin-specific allergic sensitization and airway inflammation. Am. J. Respir. Crit. Care Med 2005, I72:3|4-2I.

FI000 Factor 6

Evaluated by Bart Lambrecht 17 Feb 2012

68. Yamashita N, Tashimo $H$, Ishida $H$, Kaneko F, Nakano J, Kato $H$, Hirai K, Horiuchi T, Ohta K: Attenuation of airway hyperresponsiveness in a murine asthma model by neutralization of granulocyte-macrophage colony-stimulating factor (GMCSF). Cell. Immunol 2002, 2 19:92-7.

FI000 Factor 6

Evaluated by Bart Lambrecht 17 Feb 2012

69. Moon P, Kim H: Thymic stromal lymphopoietin is expressed and produced by caspase-I/NF- $\kappa B$ pathway in mast cells. Cytokine 20II, 54:239-43.

FI000 Factor 6

Evaluated by Bart Lambrecht 17 Feb 2012

70. Ito T, Wang Y, Duramad O, Hori T, Delespesse G], Watanabe N, Qin FX, Yao Z, Cao W, Liu Y: TSLP-activated dendritic cells induce an inflammatory $T$ helper type 2 cell response through OX40 ligand. J. Exp. Med 2005, 202:1213-23.

FI000 Factor 8

Evaluated by Mark Bix 08 Mar 20I

7I. Liu Y: Thymic stromal lymphopoietin: master switch for allergic inflammation. J. Exp. Med 2006, 203:269-73.

FI000 Factor 6

Evaluated by Bart Lambrecht 17 Feb 2012

72. Wang $Y$, Angkasekwinai P, Lu N, Voo KS, Arima K, Hanabuchi S, Hippe A, Corrigan CJ, Dong C, Homey B, Yao Z, Ying S, Huston DP, Liu Y: IL-25 augments type 2 immune responses by enhancing the expansion and functions of TSLP-DC-activated Th2 memory cells. J. Exp. Med 2007, 204:1837-47.

FI000 Factor 6

Evaluated by Bart Lambrecht 17 Feb 2012

73. Wong CK, Hu S, Cheung PFY, Lam CWK: Thymic stromal lymphopoietin induces chemotactic and prosurvival effects in eosinophils: implications in allergic inflammation. Am. J. Respir. Cell Mol. Biol 2010, 43:305-15.

FI000 Factor 6

Evaluated by Bart Lambrecht 17 Feb 2012

74. Zhang F, Huang G, Hu B, Song Y, Shi Y: A soluble thymic stromal lymphopoietin (TSLP) antagonist, TSLPR-immunoglobulin, reduces the severity of allergic disease by regulating pulmonary dendritic cells. Clin. Exp. Immunol 20II, 164:256-64

FI000 Factor 6

Evaluated by Bart Lambrecht 17 Feb 2012

75. Allakhverdi Z, Comeau MR, Jessup HK, Yoon BP, Brewer A Chartier S, Paquette N, Ziegler SF, Sarfati M, Delespesse G: Thymic stromal lymphopoietin is released by human epithelial cells in response to microbes, trauma, or inflammation and potently activates mast cells. J. Exp. Med 2007, 204:253-8.

FI000 Factor 8

Evaluated by P'ng Loke 23 Feb 2007, Marc Rothenberg 08 Mar 2007, Dale Umetsu II Apr 2007 
76. Siracusa MC, Saenz SA, Hill DA, Kim BS, Headley MB, Doering TA, Wherry EJ, Jessup HK, Siegel LA, Kambayashi T, Dudek EC, Kubo M, Cianferoni A, Spergel JM, Ziegler SF, Comeau MR, Artis D: TSLP promotes interleukin-3-independent basophil haematopoiesis and type 2 inflammation. Nature 2011, 477:229-33.

FI000 Factor 16

Evaluated by Booki Min 3I Aug 20I I, Richard Grencis 09 Sep 20II, David Voehringer 18 Nov 201I, Marc A Williams 20 Dec 2011

77. Massacand JC, Stettler RC, Meier R, Humphreys NE, Grencis RK, Marsland BJ, Harris NL: Helminth products bypass the need for TSLP in Th2 immune responses by directly modulating dendritic cell function. Proc. Natl. Acad. Sci. U.S.A 2009, 106: 13968-73.

78. Angkasekwinai P, Park H, Wang $Y$, Wang $Y$, Chang SH, Corry DB, Liu Y, Zhu Z, Dong C: Interleukin 25 promotes the initiation of proallergic type 2 responses. J. Exp. Med 2007, 204:1509-17.

FI000 Factor 6

Evaluated by Bart Lambrecht 17 Feb 2012

79. Corrigan CJ, Wang W, Meng Q, Fang C, Wu H, Reay V, Lv Z, Fan Y, An Y, Wang Y, Liu Y, Lee TH, Ying S: T-helper cell type 2 (Th2) memory $T$ cell-potentiating cytokine IL-25 has the potential to promote angiogenesis in asthma. Proc. Natl. Acad. Sci. U.S.A 201।, 108:1579-84

FI000 Factor 6

Evaluated by Bart Lambrecht 17 Feb 2012

80. Kaiko GE, Phipps S, Angkasekwinai P, Dong C, Foster PS: NK cell deficiency predisposes to viral-induced Th2-type allergic inflammation via epithelial-derived IL-25. J. Immunol 2010, 185:468I-90.

FI000 Factor 6

Evaluated by Bart Lambrecht 17 Feb 2012

8I. Dinarello CA: A signal for the caspase-I inflammasome free of TLR. Immunity 2007, 26:383-5.

FI000 Factor 6

Evaluated by Bart Lambrecht 17 Feb 2012

82. Dinarello CA: Immunological and inflammatory functions of the interleukin-I family. Annu. Rev. Immunol 2009, 27:5 I9-50.

83. Dinarello CA: Interleukin-I in the pathogenesis and treatment of inflammatory diseases. Blood 2011, I 17:3720-32.

FI000 Factor 8

Evaluated by Ulf Mueller-Ladner 28 Feb $201 \mathrm{I}$

84. Lee H, Ziegler SF: Inducible expression of the proallergic cytokine thymic stromal lymphopoietin in airway epithelial cells is controlled by NFkappaB. Proc. Natl. Acad. Sci. U.S.A 2007, 104:914-9.

85. Rusznak C, Sapsford RJ, Devalia JL, Shah SS, Hewitt EL, Lamont AG, Davies RJ, Lozewicz S: Interaction of cigarette smoke and house dust mite allergens on inflammatory mediator release from primary cultures of human bronchial epithelial cells. Clin. Exp. Allergy 200I, 3I:226-38.

FI000 Factor 6

Evaluated by Bart Lambrecht 17 Feb 2012

86. Phipps S, Lam CE, Kaiko GE, Foo SY, Collison A, Mattes J, Barry J, Davidson S, Oreo K, Smith L, Mansell A, Matthaei KI, Foster PS: Toll/ IL-I signaling is critical for house dust mite-specific ThI and Th2 responses. Am. J. Respir. Crit. Care Med 2009, 179:883-93.

FI000 Factor 7

Evaluated by Patricia Finn and Kenneth Liu 14 Jul 2009, Bart Lambrecht 17 Feb 2012

87. Layland LE, Wagner H, da Costa CUP: Lack of antigen-specific ThI response alters granuloma formation and composition in Schistosoma mansoni-infected MyD88-/- mice. Eur. Immunol 2005, 35:3248-57.

FI000 Factor 6

Evaluated by Bart Lambrecht 17 Feb 2012

88. Oboki K, Ohno T, Kajiwara N, Arae K, Morita H, Ishii A, Nambu A, Abe T, Kiyonari H, Matsumoto K, Sudo K, Okumura K, Saito H, Nakae S: IL-33 is a crucial amplifier of innate rather than acquired immunity. Proc. Natl. Acad. Sci. U.S.A 2010, 107:1858I-6.

FI000 Factor 6

Evaluated by Richard L Stevens 16 Dec 2010

89. Besnard A, Togbe D, Guillou N, Erard F, Quesniaux V, Ryffel B: IL33-activated dendritic cells are critical for allergic airway inflammation. Eur. J. Immunol 20I I, 4I:1675-86.

FI000 Factor 6

Evaluated by Joerg Koehl and Yves Laumonnier 09 Aug 2011

90. Schmitz J, Owyang A, Oldham E, Song Y, Murphy E, McClanahan TK, Zurawski G, Moshrefi M, Qin J, Li X, Gorman DM, Bazan JF, Kastelein RA: IL-33, an interleukin-Ilike cytokine that signals via the IL-I receptor-related protein ST2 and induces T helper type 2-associated cytokines. Immunity 2005, 23:479-90.

FI000 Factor 8

Evaluated by Richard Grencis 04 Jan 2006

91. Moro K, Yamada T, Tanabe M, Takeuchi T, lkawa T, Kawamoto H, Furusawa J, Ohtani M, Fujii $\mathrm{H}$, Koyasu S: Innate production of $\mathrm{T}(\mathrm{H}) 2$ cytokines by adipose tissue-associated c-Kit(+)Sca-I (+) lymphoid cells. Nature 2010, 463:540-4.

FI000 Factor 22

Evaluated by Richard Locksley 14 Jan 2010, James Disanto 19 Jan 2010, Flavius Martin and Dhaya Seshasayee OI Feb 2010, Dale Umetsu II Feb 2010, Troy Randall 24 Feb 2010, Steve Ward and John Gordon Foster 25 Feb 2010, Avinash Bhandoola 10 Jan 20II, Bart Lambrecht 17 Feb 2012

92. Fallon PG, Ballantyne SJ, Mangan NE, Barlow JL, Dasvarma A, Hewett DR, Mcllgorm A, Jolin HE, McKenzie AN]: Identification of an interleukin (IL)-25-dependent cell population that provides IL-4, IL-5, and IL-I 3 at the onset of helminth expulsion. J. Exp. Med 2006, 203:1 I05-16.

FI000 Factor 10

Evaluated by Thomas Nutman 21 Apr 2006, Thomas Wynn 28 Apr 2006

93. Neill DR, Wong SH, Bellosi A, Flynn RJ, Daly M, Langford TKA, Bucks C, Kane CM, Fallon PG, Pannell R, Jolin HE, McKenzie ANJ: Nuocytes represent a new innate effector leukocyte that mediates type-2 immunity. Nature 2010, 464:1367-70.

FI000 Factor 18

Evaluated by Torben Lund 30 Mar 2010, Lieping Chen 01 Apr 2010, Rick Maizels and James Hewitson II May 2010, Dan Conrad I4 May 2010, Bart Lambrecht 17 Feb 2012

94. Tan AM, Chen $H$, Pochard $P$, Eisenbarth SC, Herrick CA, Bottomly HK: TLR4 signaling in stromal cells is critical for the initiation of allergic Th2 responses to inhaled antigen. $J$ Immunol 20I0, 184:3535-44

FI000 Factor 6

Evaluated by Bart Lambrecht 17 Feb 2012

95. Trompette A, Divanovic S, Visintin A, Blanchard C, Hegde RS, Madan R, Thorne PS, Wills-Karp M, Gioannini TL, Weiss JP, Karp CL: Allergenicity resulting from functional mimicry of a Toll-like receptor complex protein. Nature 2009, 457:585-8.

FI000 Factor 14

Evaluated by Rene Toes and Leendert Trouw I 4 Jan 2009, Philipp M Lepper and Kathy Triantafilou 16 Feb 2009, Torben Sigsgaard and Vivi Schlunssen 29 May 2009, Michael Fessler 28 Jun 2011 
96. Vanhoutte F, Breuilh L, Fontaine J, Zouain CS, Mallevaey T, Vasseur V, Capron M, Goriely S, Faveeuw C, Ryffel B, Trottein F: Toll-like receptor (TLR)2 and TLR3 sensing is required for dendritic cell activation, but dispensable to control Schistosoma mansoni infection and pathology. Microbes Infect 9:1606-13.

FI000 Factor 6

Evaluated by Bart Lambrecht 17 Feb 2012

97. Magalhaes JG, Rubino SJ, Travassos LH, Le Bourhis L, Duan W, Sellge G, Geddes K, Reardon C, Lechmann M, Carneiro LA, Selvanantham T, Fritz JH, Taylor BC, Artis D, Mak TW, Comeau MR, Croft M, Girardin SE, Philpott DJ: Nucleotide oligomerization domaincontaining proteins instruct $\mathbf{T}$ cell helper type $\mathbf{2}$ immunity through stromal activation. Proc. Natl. Acad. Sci. U.S.A 20II, 108:|4896-90|.

FI000 Factor 6

Evaluated by Bart Lambrecht 17 Feb 2012

98. Eisenbarth SC, Colegio OR, O'Connor W, Sutterwala FS, Flavell RA: Crucial role for the Nalp3 inflammasome in the immunostimulatory properties of aluminium adjuvants. Nature 2008, 453: I I22-6.

FI000 Factor 12

Evaluated by Drusilla Burns 28 May 2008, David Chaplin 14 Jul 2008, Dale Umetsu 28 Jul 2008, Shizuo Akira 09 Sep 2008

99. Kuroda E, Ishii KJ, Uematsu S, Ohata K, Coban C, Akira S, Aritake K, Urade $Y$, Morimoto $Y$ : Silica crystals and aluminum salts regulate the production of prostaglandin in macrophages via NALP3 inflammasome-independent mechanisms. Immunity 20II, 34:514-26.

FI000 Factor 6

Evaluated by Bart Lambrecht 17 Feb 2012

100. Marrack P, McKee AS, Munks MW: Towards an understanding of the adjuvant action of aluminium. Nat. Rev. Immunol 2009, 9:287-93.

FI000 Factor 6

Evaluated by Bart Lambrecht 17 Feb 2012

10I. Schmitz N, Kurrer M, Kopf M: The IL-I receptor I is critical for Th2 cell type airway immune responses in a mild but not in a more severe asthma model. Eur. J. Immunol 2003 33:991-1000.

FI000 Factor 6

Evaluated by Bart Lambrecht 17 Feb 2012

102. Li H, Willingham SB, Ting JP, Re F: Cutting edge: inflammasome activation by alum and alum's adjuvant effect are mediated by NLRP3. J. Immunol 2008, I8I:17-2I.

FI000 Factor 8

Evaluated by Denise M Monack 23 Jul 2008

103. McKee AS, Munks MW, MacLeod MKL, Fleenor CJ, van Rooijen N, Kappler JW, Marrack P: Alum induces innate immune responses through macrophage and mast cell sensors, but these sensors are not required for alum to act as an adjuvant for specific immunity. J. Immunol 2009, 183:4403-I4.

FI000 Factor 6

Evaluated by Bart Lambrecht 17 Feb 2012

104. Franchi L, Núñez G: The NIrp3 inflammasome is critical for aluminium hydroxide-mediated IL-I beta secretion but dispensable for adjuvant activity. Eur. J. Immunol 2008, 38:2085-9.

FI000 Factor 7

Evaluated by Moriya Tsuji 03 Sep 2008, Bart Lambrecht I7 Feb 2012

105. Kool M, Pétrilli V, Smedt T de, Rolaz A, Hammad H, van Nimwegen M, Bergen IM, Castillo R, Lambrecht BN, Tschopp J: Cutting edge: alum adjuvant stimulates inflammatory dendritic cells through activation of the NALP3 inflammasome. J. Immunol 2008, 181:3755-9.

106. Dai X, Sayama K, Tohyama M, Shirakata Y, Hanakawa Y, Tokumaru S, Yang L, Hirakawa S, Hashimoto K: Mite allergen is a danger signal for the skin via activation of inflammasome in keratinocytes. J. Allergy Clin. Immunol 20II, I27:806-I4.el-4.

107. Barrett NA, Rahman OM, Fernandez JM, Parsons MW, Xing W, Austen KF, Kanaoka Y: Dectin-2 mediates Th2 immunity through the generation of cysteinyl leukotrienes. J. Exp. Med 2011, 208:593-604.

FI000 Factor 6

Evaluated by Bart Lambrecht 17 Feb 2012 